\title{
VECTOR ASPECTS IN RISK AREAS FOR SYLVATIC YELLOW FEVER IN THE STATE OF MATO GROSSO DO SUL, BRAZIL
}

\author{
Paulo Silva de Almeida ${ }^{1}$, José Oliveira da Silva ${ }^{1}$, Ezequiel Pereira Ramos ${ }^{1}$, \\ Paulo Mira Batista ${ }^{2}$, Odival Faccenda ${ }^{3}$, Marcia Bicudo de Paula ${ }^{4}$, Hamilton \\ Antônio de Oliveira Monteiro ${ }^{5}$ and Luis Filipe Mucci' ${ }^{6}$.
}

\begin{abstract}
Epizootics and yellow fever epidemics in 2008 in Brazil, Paraguay and Argentina marked a significant progression of the disease further south in the continent affecting non-vaccinated human populations. The state of Mato Grosso do Sul is located between the tropical endemic region and the subtropical epidemic region and, despite being an area recommended for vaccination since the 1980s, human and animal cases of the disease are still registered. The purpose of this study was to present the results of entomological surveys of probable sites of infection (PSI) geographically describing these areas regarding human cases and disease suspicion reported in 2008. Thirteen locations in nine municipalities were investigated. A total of 305 females of the genus Haemagogus and Sabethes and five specimens of Aedes albopictus were obtained. The genus Haemagogus was more abundant but Sabethes presented twice as many species $(3 \times 6)$ and higher distribution within the collection points. The most abundant species was Hg. janthinomys, with 102 individuals in one location. The other species found were: Hg. leucocelaenus, Hg. spegazzinii, Sa. albiprivus, Sa. belisarioi, Sa. chloropterus, Sa. glaucodaemun, Sa. intermedius and $\mathrm{Sa}$. soperi. It was not possible to identify predominant species in relation to environmental and geographical characteristics of the collection points. Of the nine human cases, eight corresponded to persons not resident in the State, seven of them tourists. MS features a large diversity of rural and wildlife tourist attractions where the yellow fever vectors described in this work are present. In this sense, the monitoring of vaccination coverage and flow of non-vaccinated people through the area are crucial to controlling the disease.
\end{abstract}

KEY WORDS: Surveillance; culicidae; yellow fever.

1. Regional Entomology Laboratory, Regional Health Unit, State Department of Health, Dourados, MS, Brazil.

2. State Service for the Coordination of Epidemiologic Surveillance, Mato Grosso do Sul State Department of Health, Campo Grande, MS, Brazil.

3. Federal University of Dourados, Cidade Universitária, Dourados, MS, Brazil.

4. Department of Epidemiology, School of Public Health, University of São Paulo, São Paulo, SP, Brazil.

5. Department of Health Surveillance, Evandro Chagas Institute, Ministry of Health, Ananindeua, PA, Brazil.

6. Department of Specialized Laboratories, Superintendence for Endemic Disease Control, State Health Secretariat, Taubaté, São Paulo State, Brazil.

Corresponding author: Paulo Silva de Almeida. E-mail: psilvadealmeida@yahoo.com.br 


\section{RESUMO}

Aspectos vetoriais em áreas de risco para febre amarela silvestre no Estado do Mato Grosso do Sul, Brasil.

As epidemias e epizootias de febre amarela ocorridas em 2008 no Brasil, Paraguai e Argentina marcaram um expressivo avanço da doença para o sul do continente, afetando populações humanas não vacinadas. O estado de Mato Grosso do Sul encontra-se na transição entre a região endêmica tropical e a epidêmica subtropical e, apesar de ser considerado área de recomendação para vacinação desde a década de 1980, ainda registra casos humanos e epizootias. O objetivo deste trabalho foi apresentar os resultados de levantamentos entomológicos em locais de casos humanos e epizootias notificados como suspeitos em 2008, descrevendo geograficamente essas áreas. Foram investigadas 13 localidades em nove municípios, tendo sido obtidas 305 fêmeas dos gêneros Haemagogus e Sabethes, além de cinco espécimes de Aedes albopictus. O gênero Haemagogus foi mais abundante, mas Sabethes apresentou o dobro de espécies (3 x 6) e maior distribuição entre os pontos de coleta. A espécie mais abundante foi Hg. janthinomys, porém com 102 indivíduos em um único local. As demais espécies encontradas foram: $\mathrm{Hg}$. leucocelaenus, $\mathrm{Hg}$. spegazzinii, Sa. albiprivus, Sa. belisarioi, Sa. chloropterus, Sa. glaucodaemun, Sa. intermedius e Sa. soperi. Não foi possível identificar tendências de preferência das espécies em relação aos atributos ambientais e geográficos descritos para os pontos de coleta. Dos nove casos humanos, oito corresponderam a pessoas não residentes no estado, sendo sete turistas. O estado de Mato Grosso do Sul reúne grande diversidade de atrativos turísticos relacionados com ambientes rurais e silvestres, onde o homem pode entrar em contato com os vetores da febre amarela encontrados neste trabalho. Nesse sentido, o monitoramento da cobertura vacinal e do fluxo de pessoas não vacinadas é fundamental para o controle da doença.

DESCRITORES: Vigilância; culicidae; febre amarela.

\section{INTRODUCTION}

Sylvatic yellow fever (SYF) is found in tropical forests in Africa and Central and South America (Monath and Vasconcelos, 2015). First recorded in Brazil in 1930, SYF occurs in the Legal Amazon and outside it, in regions which can be divided into endemic, non-endemic and transition areas (Tuboi et al., 2007; Jentes et al., 2011). The geographic spread of SYF is a cause for concern (Tauil, 2010; Romano et al., 2011). It manifests endemically and sporadically, while the urban form, which has not been detected in Brazil since the 1940s, could return given the multiplication of non-human primates (NHP), epizootic outbreaks and the widespread infestation of urban centers by Aedes aegypti (Tauil, 2010). This possibility has grown with the recent emergence of urban foci in Bolivia (Van der Stuyft et al., 1999) and Paraguay (OPAS, 2008), where SYF is acquired not only by local inhabitants, but also by visitors to rural areas and tourists.

Although there is an effective vaccine, surveillance is hindered by the difficulty in understanding the dynamics of yellow fever transmission (Costa et al., 2011) and consequently by the lack of precise indicators that are vital for modeling and planning preventive measures (Moreno \& Barata, 2011; Ribeiro et al., 2015). In this sense, entomological surveys related to transmission events are 
fundamental for better understanding the ecology and biology of the vectors of this disease, and to allow viral isolation, mainly when it is not possible to collect samples of both human cases and animal diseases (Romano et al., 2011).

In Brazil, the major mosquito vectors of SYF are Haemagogus janthinomys and $\mathrm{Hg}$. leucocelaenus, due to more frequent viral isolations resulting from investigations in epidemics and epizootic sites (Vasconcelos, 2003; Vasconcelos, 2010). In general, the former is more associated to transmissions in the North and Central regions and the latter, in the South and Southeast. Others species of the genus Haemagogus and Sabethes are considered secondary or even locally important in the absence of the main one (Vasconcelos, 2003; Vasconcelos et al., 2013). Species of the genus Aedes and Psorophora had yet to present natural and experimental infections (Davis and Shannon, 1931; Vasconcelos, 2003) and, most recently, entomological surveys related to outbreaks in 2008 in Rio Grande do Sul (RS) and in 2008/2009 in São Paulo (SP) resulted in viral isolations of Ae. serratus (Cardoso et al, 2010) and Ps. ferox (Moreno et al., 2011). These findings reinforced the suggestion of new potential secondary vector species in Subtropical regions and Tropical boundaries.

In regard to the states above, 2008 was an outstanding year for Mato Grosso do Sul (MS) for SYF transmission, as nine human cases were confirmed (two deaths) and two epizootics between January and February (Table 1) (Ramos, 2013). Unfortunately, that year there was an increase in the occurrences of SYF in Brazil, with confirmed human cases in nine states and four regions (MS/SVS, 2011a), including the large number of NHP deaths and epizootics throughout the country (Romano et al., 2014). The same was noted in neighboring countries, particularly urban cases in Paraguay (OPAS, 2008) and SYF epidemics/ epizootics in the Misiones Province, Argentina (Goenaga et al., 2012).

With a view to increasing existing knowledge on the subject of SYF in South America, the purpose of this study was to present the results of entomological surveys in areas where SYF human cases and epizootics were notified in 2008 in the State of Mato Grosso do Sul, as well as to describe the different geographical characteristics of these localities.

\section{MATERIAL AND METHODS}

Study area: MS is located in the Brazilian Midwest, comprising an area of $358,200 \mathrm{~km}^{2}$. It borders the states of Minas Gerais, São Paulo and Paraná to the east and Mato Grosso and Goiás to the north. Moreover, MS has international borders with Bolivia and Paraguay. The state has 79 counties, distributed into 11 micro-regions and four meso- regions (East, Mid-north, Southwest and the wetlands "Pantanais"), with an estimated population of approximately 2.68 million inhabitants (IBGE, 2016). Paraguay and Paraná river watersheds divide the state practically in half from east to west, including 15 sub-watersheds 
(SEPLAN/MS, 1990). The diversity in geologic structure (Lastoria et al., 2006), climate classification (Zavattini, 2009) and vegetation Biomes (Silva et al., 2010) may also be noted.

The state of MS is in a climatic and phytogeographic transition area. Regarding the types of climate, the southern half of the state is a humid subtropical domain zone while the northern half is a humid tropical area alternately wet and dry. The four major regions are differentiated by the presence of the following air masses: Polar Atlantic; Tropical Continental; Tropical Atlantic and Equatorial Continental (A1, A2, B1, B2), divided into eleven types of regional climate, characterized by rainfall and structural elements of relief, as for example the Bodoquena and Maracaju Mountain ranges, and the wetlands of the Pantanal (Zavattini, 2009).

As for vegetation, remnants of the Atlantic forest cover the banks of the Paraná river and a larger portion of the south of the state, the Cerrado encompasses wide areas from the northeast to the southwest, with influence from the Chaco to the south-southwest, while the Pantanal is influenced by the Amazon in the northwest. The following forests are to be found: Riparian forests in all areas, deciduous and semi-deciduous forests, "Cerradão" and transition compositions, including seasonally flooded vegetation (Silva et al., 2010).

Epidemiology: SYF had occurred consistently since the 1930's in the region within the current political borders of the state, except during the 1940's (Costa, 2009). Considering the events after 1979, when the state was officially founded, seventeen human cases were registered in 1981/82 all resulting in death; in 1991/92, fourteen cases were registered, seven of which evolved to deaths and finally, in 1996, only one case (death) (MS/SVS, 2009). Indeed, the percentages of accumulated vaccination coverage per county reached almost $125 \%$ for the whole of MS from 1991 to 2001 (Benchimol, 2001). Subsequently, between 2001 and 2011, vaccination coverage was higher than $90 \%$ for most counties and not under $60 \%$ for the remaining (MS/SVS, 2011a). In relation to epizootics, since 1999 the Brazilian Ministry of Health has established the surveillance of NHP epizootics and as from 2006 determined compulsory notification (Costa et al., 2011). Therefore, epizootics were registered in 2000, 2003 and 2007, prior to 2008 when nine human cases were confirmed in probable infection sites (PSI) in five different counties: Água Clara, Aral Moreira, Bonito, Maracaju and Ribas do Rio Pardo (SSCES/State Department of Health-MS, 2008). Bela Vista and Ponta Porã were alternative counties in epidemiological investigations for the case closed in Aral Moreira; basic information referring to confirmed cases is presented in Table 1. Regarding epizootics, two NHP deaths in Anastácio and Corumbá were confirmed as SYF. Aquidauana was the alternative county in investigations for the case closed in Anastácio and the other suspected death occurred in Campo Grande but could not be confirmed as epizootic (MS/SVS, 2011a). Figure summarizes the distribution of SYF events between 1981 and 2008. 


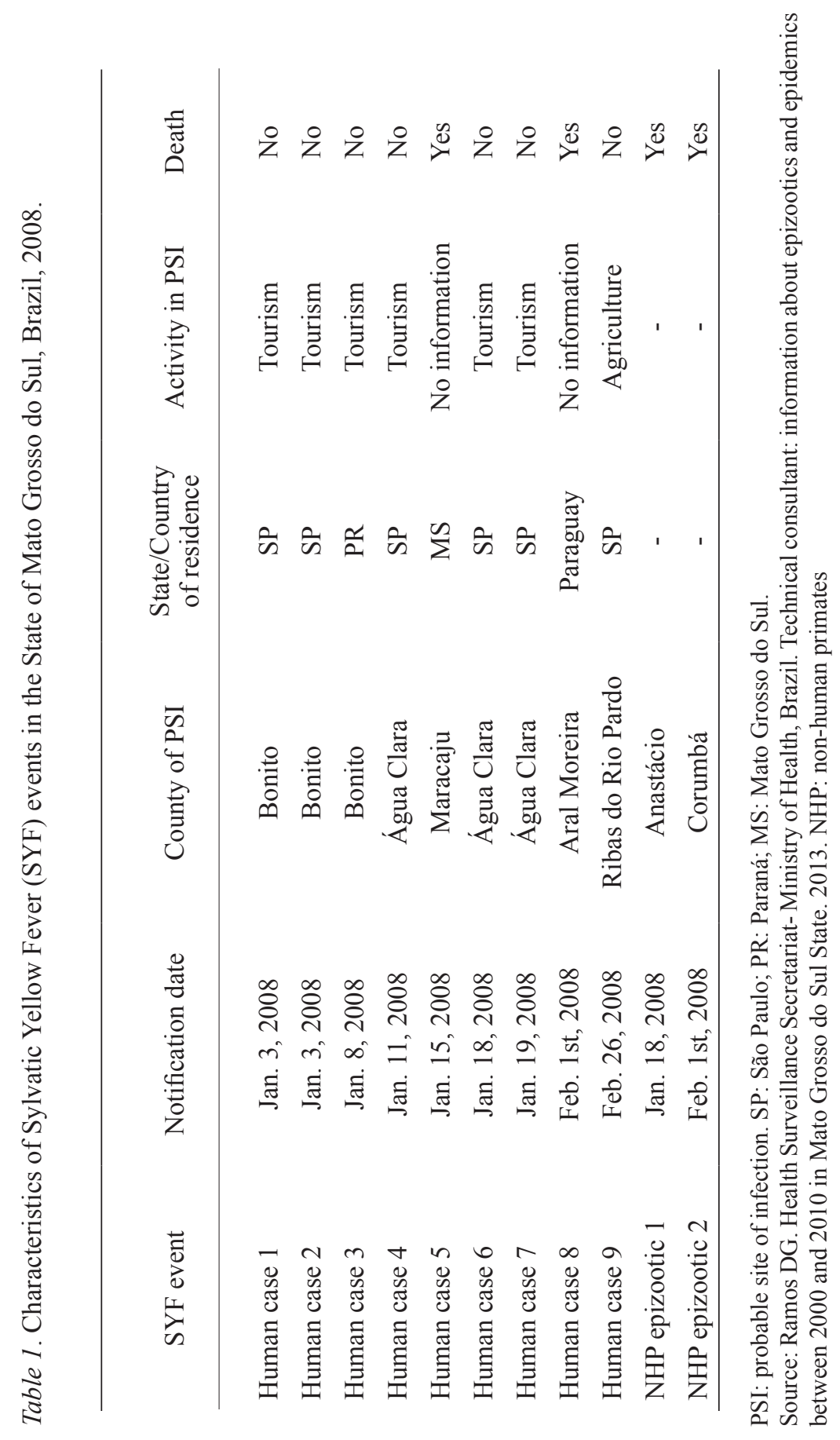


Collection sites: The MS Department of Health Surveillance encourages entomological surveys during epizootic events or in areas where human infection is likely to occur in order to record the presence of known SYF vectors. However, not all counties with suspected notifications were selected due to operational limitations (i.e.: Maracaju), and some of the selected counties had not presented subsequent confirmations of autochthonous cases and diseases (i.e.: Aquidauana, Bela Vista and Campo Grande). Thus, the selected counties for collections were: Água Clara, Anastácio, Aquidauana, Aral Moreira, Bela Vista, Bonito, Campo Grande, Corumbá e Ribas do Rio Pardo (Figure). Samples were collected inside forest remnants and riparian forest found in PSIs, preferably where the canopy was best preserved, with the highest number of mature trees, and the most humid microclimate. The quality and degree of environmental preservation/degradation of the locations varied as some of them are located in the vicinity of urban areas. Table 2 shows the environmental characteristics of each collection site.

Collection scheme: Adult culicids were collected with Castro capture devices and insect nets on 2-4 consecutive days between January and April, 2008 (collection dates in Table 2). Captures at ground level were carried out from 9 am to $3 \mathrm{pm}$. There were four collectors in each site, except in Bonito, where there were six. All the specimens collected were preserved in liquid nitrogen in appropriate containers for viral isolation at a later date (not presented in this study). Species identification was performed by the Evandro Chagas Institute in the State of Pará. The abbreviations of the names followed Reinert (2001).

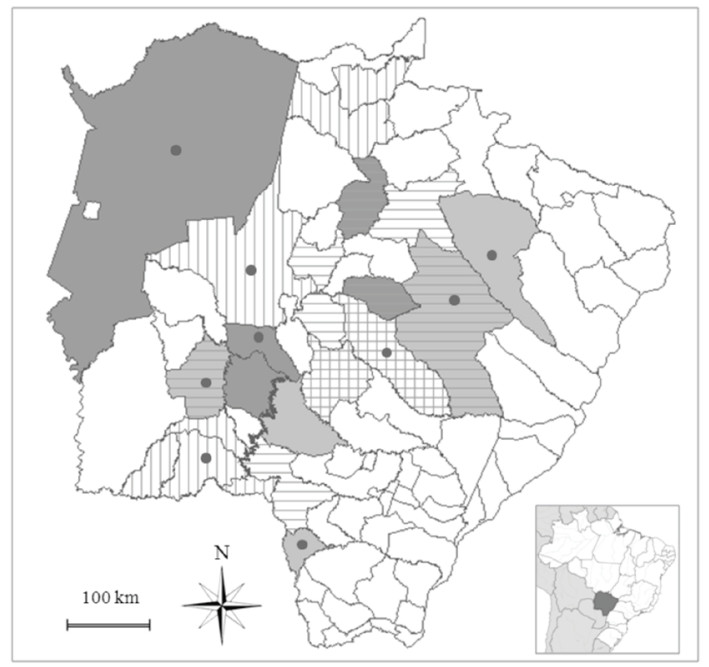

Figure. Counties of Mato Grosso do Sul with epidemics and epizootics between 1981 and 2008 (vertical lines: human cases in 1981-2; horizontal lines: human cases in 1991-2 and 1996; dark grey: NHP epizootics in 2000, 2003, 2007-8; ligth grey: human cases in 2008) and counties selected for entomological surveys in 2008 (points). 


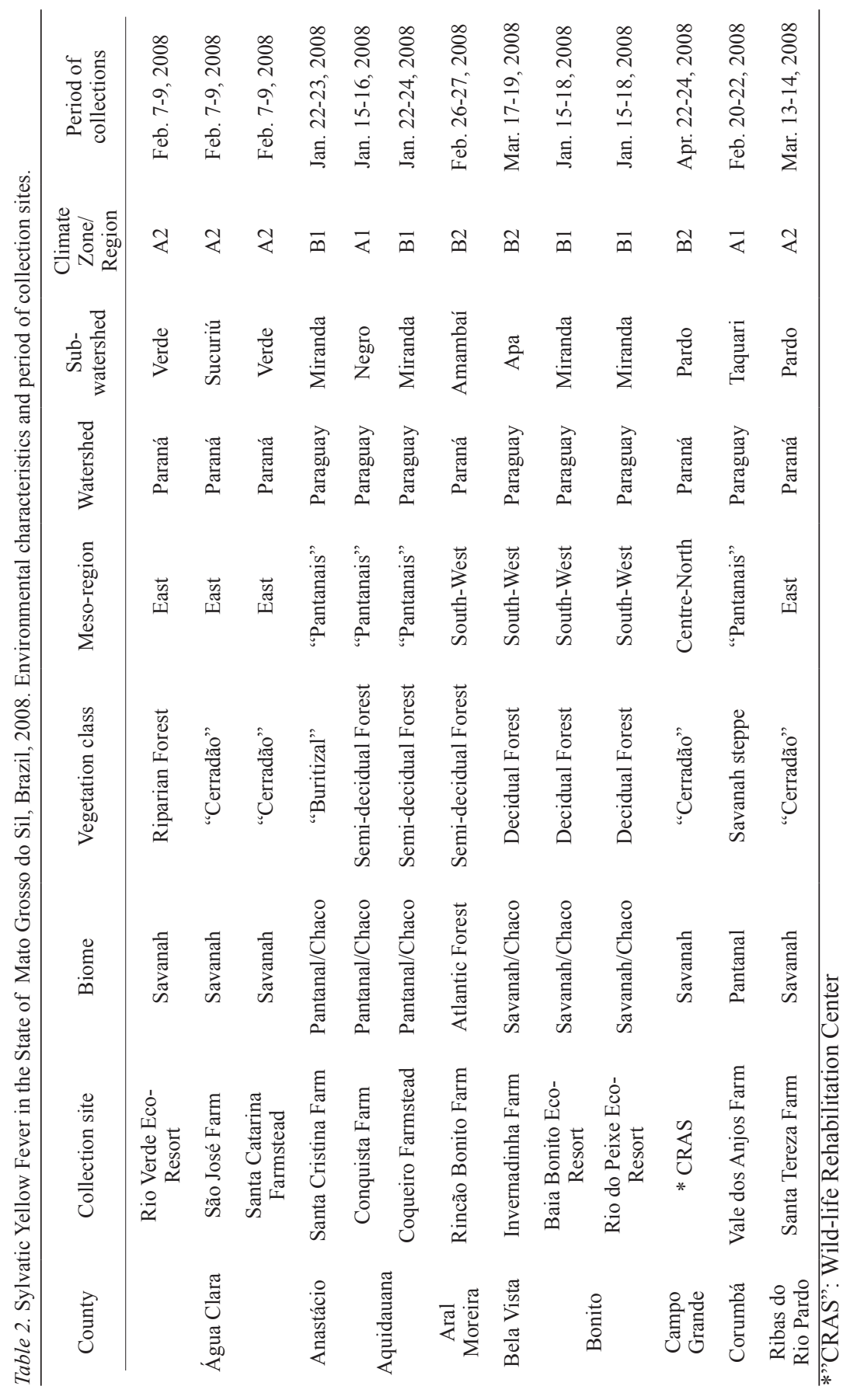




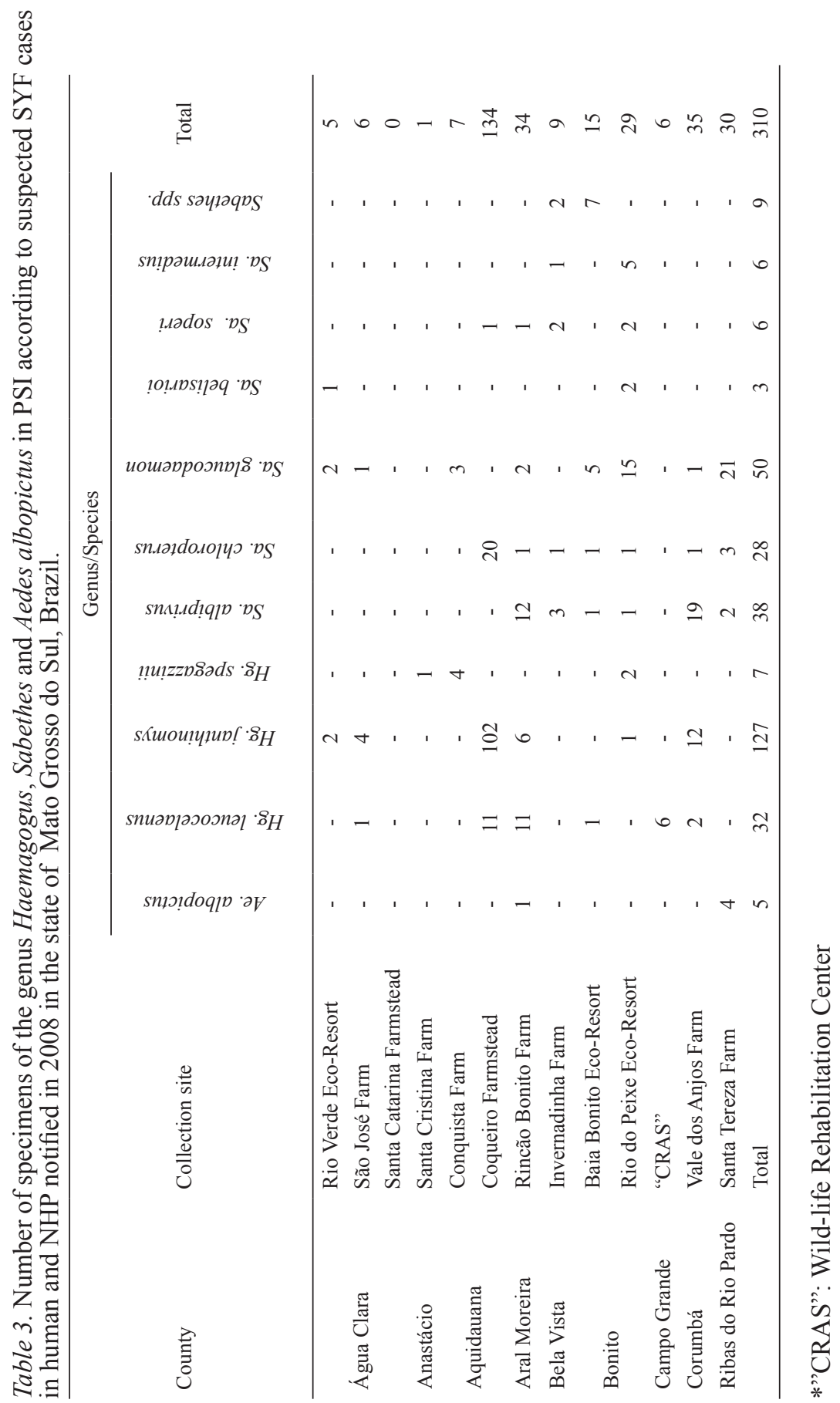

Rev Patol Trop Vol. 45 (4): 398-411. out.-dez. 2016 


\section{RESULTS}

For all thirteen locations investigated, 305 females from genus Haemagogus and Sabethes and five specimens of Aedes albopictus were obtained (Table 3). The genus Haemagogus was abundant but Sabethes presented twice the number of species $(3 \times 6)$ and greater distribution among the collection points. The most abundant species was Hg. janthinomys, with 102 individuals in one location. The most common species in the collection points was $\mathrm{Sa}$. glaucodaemun found in eight locations, followed by Sa. chloropterus in seven; the main vectors $H g$. janthinomys and Hg. leucocelaenus were found in six locations, as well as $\mathrm{Sa}$. albiprivus. The other species collected were: $\mathrm{Hg}$. spegazzinii, Sa. belisarioi, Sa. intermedius and Sa.soperi. Identification of the species level was not possible in nine specimens of the genus Sabethes.

Regarding the environment of the collection sites (Table 2), there was a great variety of combinations in climate class, sub-basins, meso-regions, biome and vegetation classes within the sites, except for the two sites in Bonito. As for the others, there is no other match, unless the sub-basin variable is excluded from the set of attributes; therefore the Santa Tereza Farm (Ribas do Rio Pardo), Santa Catarina and São José Farmstead (both in Água Clara) also begin to present the same combinations of attributes. As for the characteristics of the nine confirmed human cases, information was obtained for seven regarding activities in PSIs, six of which were tourists. It is noteworthy that only one of the cases was a resident in the state.

\section{DISCUSSION}

The main result of this work was to note the abundance of mosquitoes potentially associated with SYF transmission in locations of suspected animal and human cases reported in 2008 in the state of Mato Grosso do Sul. Some of the results were obtained in places where later infections were not confirmed. This, in a way, was due to the immediate action of epidemiological and entomological surveillance institutions (state and federal) in triggering investigations in the field, namely, warning systems and the coordination and preparation of public health services.

Another important aspect is the operational evaluation in relation to the entomological results. The collection scheme and techniques used in this study followed the protocol recommended by the Brazilian Ministry of Health, which was only later published in technical standard (MS/SVS, 2011b). Considering the sampling effort of 2-4 consecutive days and collections by 4-6 individuals, it is noted that the species richness of Haemagogus and Sabethes obtained for the whole set of thirteen locations ( 9 species) was considerable in relation to previous studies (Camargo-Neves et al., 2005; Mucci et al, 2015). The abundance of specimens, however, was not sufficient for forwarding 
samples for virus isolation attempts in most places. Possibly double or triple efforts in the field and the concomitant use of other methods not requiring human presence will produce better results. In Brazil, some comparisons between different traps and mosquito attractants have been reported in the Atlantic forest area (Sá \& Sallum, 2013).

The results did not cover which species was probably responsible for virus transmission in a particular locality, or even point out tendencies regarding the presence of the species or of each species to the types of environmental combinations and geographical attributes described for the places investigated. Even so, the ecological eclecticism of these species is noteworthy considering the variability of these attributes (Table 2). In fact, the transitional character of the state of MS, in relation to climate and vegetation, can interfere in a number of ecological, genetic and parasite-vector interactions in the populations of these species of mosquitoes, affecting the vectorial capacity of some of these, as noted for Anopheles in malaria transmission, in a number of future scenarios (Laporta et al, 2015, Lorenz et al, 2015). Added to this ecological transitional feature, there is the fact that MS is crisscrossed by different highways and waterways linking the Amazonian region to the south and southeast of the country, in addition to the international flow with neighboring countries that have recently become more receptive to the sylvatic and urban forms of yellow fever (van der Stuyft et al., 1999, OPAS, 2008, Goenaga et al, 2012).

In this sense, the presence of Ae. albopictus in wild areas close to urban areas can pose a major threat to the transfer of yellow fever virus from the rural/sylvatic environment to the towns, which has been emphasized for about 20 years based on findings in the same State (Gomes et al., 1999). In Brazil, both Ae. albopictus as Ae. aegypti have demonstrated vector competence for the yellow fever virus (Lourenço-de-Oliveira et al., 2003; Lourenço-deOliveira et al., 2004).

Among the species of the genus Haemagogus, besides the already known importance of $\mathrm{Hg}$. janthinomys and $\mathrm{Hg}$. leucocelaenus, records of high abundance of $\mathrm{Hg}$. spegazzinii suggest the possibility of its participation in the enzootic cycle of the disease (Kumm \& Cerqueira, 1951). Regarding the genus Sabethes, all species collected in this study were found naturally infected except Sa. intermedius (Segura \& Castro, 2007; Vasconcelos et al., 2013). The species of the genus, $\mathrm{Sa}$. chloropterus is considered the main vector species of SYF due to the frequency of natural infection findings from the center to the north of country (Vasconcelos et al., 1997; Vasconcelos, 2003; Vasconcelos et al., 2013). Regarding Sa. albiprivus, the finding of natural infection in Argentina and the confirmation that this was the species responsible for transmitting SYF in the Misiones Province in 2008 (Goenaga et al., 2012) is also cause for concern since the species was relatively well distributed and abundant among the areas surveyed. Epizootics and epidemics occurring in 2008 proved not only the vulnerability of South American cities in re-establishing urban 
transmission, as well as the intense flow of non-vaccinated people to risk areas (OPAS, 2008, Goenaga et al., 2012, Romano et al., 2014). The fact that seven of the nine human cases came from tourist attraction spots, revealed miscommunication regarding the yellow fever immunization program within the health services, tourism services and consumer population. The state of MS presents a great diversity of attractions classified as ecotourism, adventure and specialized tourism as well as recreational tourism (Barbosa and Zamboni, 2000). These activities are generally performed in rural or sylvatic places, such as bird and animal watching, fishing, freshwater diving, speleology and farm tourism (Barbosa and Zamboni, 2000; Pivatto and Sabino, 2007; Lobo and Moretti, 2009; Oliveira et al., 2009).

Unfortunately, like most of the infections that occurred in 2008, the last case notified in 2015 was again a tourist, specifically involved in fishing, non-resident in the state (Promed, 2015). On the other hand, another human case (post-2008) in 2010 was recorded from a native resident (Ramos, 2013). This suggests inadequate immunization programs in areas supposedly with vaccination against yellow fever. In fact, comparing the vaccination coverage between the periods 1991-2001 (Benchimol, 2001), 2001-2011 (MS/SVS, 2011a) and 2011-2013 (MS/SVS, 2014), MS state shows a sharply declining trend. According to Vasconcelos (2010), a combination of five factors is likely to be associated with the reemergence of yellow fever in southern and southeastern Brazil after 2008: exposure of a susceptible human population; high density of vectors and primary hosts (NHP); favorable climate conditions, especially increased rainfall; emergence of a new genetic lineage; and circulation of people and/or infected monkeys. Probably, the same processes were involved in epizootics and epidemics in 2008 in Argentina and Paraguay. Perhaps a more detailed assessment of climatic phenomena incidents throughout the affected area in 2008 (from Pará to Rio Grande do Sul, from Paraguay to Southern São Paulo) could increase the understanding of risk factors. In this case, there is already a regular source of information available, i.e. the systematic monitoring of meteorological variables for agriculture.

However, considering parameters more directly related to the forces of infection, such as: Virus replacements ("boom-and-bust cycle"), high population densities of SYF vectors and transovarial transmission, a proposal for entomological-viral monitoring at strategic locations, especially in transition regions with areas without vaccination recommendation, could represent a major breakthrough for the surveillance system (Romano et al., 2011). One of the major gains would be subsidies provided to improve immunization strategies in an attempt to avoid or reduce the impacts of emergency mass vaccination campaigns, when problems arise such as increased rates of adverse reactions to the vaccine (Mascheretti et al., 2013), or vaccine stocks running out (Jentes et al., 2011, Yen et al., 2015). 


\section{REFERENCES}

1. Barbosa MAC, Zamboni RA. Texto para discussão no 772: Formação de um 'Cluster' em Torno do Turismo de Natureza Sustentável em Bonito - MS. IPEA. Brasília, 2000.

2. Benchimol JL (coord.). Febre amarela: a doença e a vacina, uma história inacabada. Editora FIOCRUZ. Rio de Janeiro, 2001.

3. Camargo-Neves VLF, Poletto D W, Rodas LAC, Pachioli ML, Cardoso-Jr RP, Scandar AS, Sampaio SMP, Koyanagui PH, Botti MV, Mucci LF, Gomes AC. Entomological investigation of a sylvatic yellow fever area in São Paulo State, Brazil. Cad Saúde Pública 21: 1278-1286, 2005.

4. Cardoso JC, Almeida MAB, Santos ES, Fonseca DF, Sallum MAM, Noll CA, Monteiro HAO, Cruz ACR, Carvalho VL, Pinto EV, Castro FC, Nunes-Neto JP, Segura MNP, Vasconcelos PFC. Yellow fever virus in Haemagogus leucocelaenus and Aedes serratus mosquitoes, Southern Brazil, 2008. Emerg Infect Dis 16: 1918-1924, 2010.

5. Costa ZGA. Febre amarela: situação epidemiológica no Brasil. 2009. Ministry of Health, Brazil. Training presentation for professionals for medical public assistance. Available: http://docplayer.com.br/6880609-Situacao-epidemiologica-da-febre-amarela-no-brasil.html. Accessed in Jun, 2016.

6. Costa ZGA, Romano APM, Elkhoury ANM, Flannery B. Evolução histórica da vigilância epidemiológica e do controle da febre amarela no Brasil. Rev Pan-Amaz Saude 2: 11-26, 2011.

7. Davis NC, Shannon RC. Studies on yellow fever in South America. Attempts to transmit the virus with certain Aedine and Sabethine mosquitoes and with Triatomas (Hemiptera). Am J Trop Med Hyg 11: 21-29, 1931.

8. Goenaga S, Fabbri C, Rossi GC, Duenas JCR, Garcia JB, Rondan JC, Braulio J, Calderon G, Enria DA. Isolation of Yellow Fever Virus from Mosquitoes in Misiones Province, Argentina. Vector Borne Zoonotic Dis 12: 11, 2012.

9. Gomes AC, Bitencourt MD, Natal D, Pinto PLS, Mucci LP, Paula MB, Urbinatti PR, Barata JMS. Aedes albopictus em área rural do Brasil e implicações na transmissão de febre amarela silvestre. Rev Saúde Pública 33: 95-97, 1999.

10. Instituto Brasileiro de Geografia e Estatística. Rio de Janeiro: IBGE; 2016. Disponível em http://www.ibge.gov.br/estadosat/perfil.php?sigla=ms\#. Accessed in Jul, 2015.

11. Jentes ES, Poumerol G, Gershman MD, Hill DR, Lemarchand J, Lewis RF, Staples JE, Tomori O, Wilder-Smith A, Monath TP, WHO Working Group on Geographic Risk for Yellow Fever. The revised global yellow fever risk map and recommendations for vaccination, 2010: consensus of the Informal WHO Working Group on Geographic Risk for Yellow Fever. Lancet Infect Dis 11: 622-632, 2011.

12. Kumm, HW, Cerqueira NL. The role of Aedes leucocelaenus in the epidemiology of jungle yellow fever in Brazil. Bull Entomol Res 42:195-199, 1951.

13. Laporta GZ, Linton YM, Wilkerson RC, Bergo ES, Nagaki SS, Sant'Ana DC, Sallum MA. Malaria vectors in South America: current and future scenarios. Parasit Vectors 8: 426, 2015.

14. Lorenz C, Virginio F, Aguiar BS, Suesdek L, Chiaravalloti-Neto F. Spatial and temporal epidemiology of malaria in extra-Amazonian regions of Brazil. Malaria J 14: 408, 2015.

15. Lastoria G, Sinelli O, Kiang CH, Hutcheon I, Paranhos-Filho AC, Gastmans D. Hidrogeologia da formação Serra Geral no Estado de Mato Grosso do Sul. Águas Subt 20: 139-150, 2006.

16. Lourenço-de-Oliveira R, Vazeille, M, Filipis AMB, Failloux AB. Large genetic differentiation and low variation in vector competence for dengue and yellow fever viruses of Aedes albopictus from Brazil, the United States and the Cayman Islands. Am J Trop Med Hyg 69: 105-114, 2003. 
17. Lourenço-de-Oliveira R, Vazeille, M, Filipis AMB, Failloux AB. Aedes aegypti in Brazil: genetically differentiated populations with high susceptibility to dengue and yellow fever viruses. Trans R Soc Trop Med Hyg 98: 43-54, 2004.

18. Lobo HAS, Moretti EC. Tourism in caves and the conservation of the speleological heritage: the case of the Serra da Bodoquena (mato Grosso do Sul State, Brazil). Acta Carsol 38: 265 276, 2009.

19. Mascheretti M, Tengan CH, Sato HK, Suzuki A, de Souza RP, Maeda M, Brasil R, Pereira M, Tubaki RM, Wanderley DMV, Fortaleza CMCB, Ribeiro AF and Yellow Fever Group. Yellow fever: reemerging in the state of São Paulo, Brazil, 2009. Rev Saude Publica 47: 1-9, 2013.

20. Ministério da Saúde/Secretaria de Vigilância em Saúde, Brasil (MS/SVS). Casos e óbitos por Febre Amarela, Brasil, 1980-2009. Consulta eletrônica- Coordenação Geral de Doenças Transmissíveis, GT-Febre amarela. Brasília, 2009.

21. Ministério da Saúde/Secretaria de Vigilância em Saúde, Brasil (MS/SVS). Situação epidemiológica da Febre Amarela Silvestre no Brasil. Monitoramento 2010/2011. Boletim de atualização- Coordenação Geral de Doenças Transmissíveis. Brasília, 2011a.

22. Ministério da Saúde/Secretaria de Vigilância em Saúde, Brasil (MS/SVS). b. Recomendações de priorização das atividades de investigação entomológica e padronização dos métodos de coleta de amostras para diagnóstico laboratorial de Febre Amarela. Nota Técnica ${ }^{\circ}$ 59Coordenação Geral de Doenças Transmissíveis. Brasília, 2011b.

23. Ministério da Saúde/Secretaria de Vigilância em Saúde, Brasil (MS/SVS). Aspectos epidemiológicos da febre amarela silvestre e a vigilância intensificada durante período de monitoramento, Brasil, 2012/2013. Boletim epidemiológico 45: 7. Brasília, 2014.

24. Monath TP, Vasconcelos PFC. Yellow fever. J ClinVirol 64: 160-173, 2015.

25. Moreno ES, Barata RCB. Municipalities of higher vulnerability to sylvatic yellow fever occurrence in the São Paulo State Brazil. Rev Inst Med Trop Sao Paulo 53: 335-339, 2011.

26. Moreno ES, Rocco IM, Bergo ES, Brasil RA, Mascheretti M, Akemi S, Silveira VR, Bisordi I, Souza RP, Yellow Fever Working Group. Reemergence of yellow fever: detection of transmission in the State of São Paulo, Brazil, 2008. Rev Inst Med Trop Sao Paulo 44: 290296, 2011.

27. Mucci LF, Cardoso-Júnior RP, Paula MB, Scandar SAS, Pacchioni ML, Fernandes A, Consales CA. Feeding habits of mosquitoes (Diptera: Culicidae) in an area of sylvatic transmission of yellow fever in the state of São Paulo, Brazil. J Venom Anim Toxins incl Trop Dis 21: 6, 2015.

28. Oliveira LD, Pinheiro LEP, Michels IL. Caracterização da Cadeia Turística do Mato Grosso do Sul. Tur Anal 20: 210-229, 2009.

29. Organización Panamericana de la Salud (OPAS). Brote de fiebre amarilla en Paraguay. Bol Epidemiol 27: 1, 2008.

30. Pivatto MAC, Sabino J. Infra-estrutura receptiva para o turismo de observação de aves no Pantanal Sul e Planalto da Bodoquena, Mato Grosso do Sul. Observ Inov Tur 2: 1-11, 2007.

31. Promed. International Society for Infectious Diseases. Archive number: 20150506.3346281, 06/05/2015. http://www.promedmail.org/post/20150506.3346281. Accessed in Aug, 2016.

32. Ramos DG. Health Surveillance Secretariat- Ministry of Health, Brazil. Technical consultant: information about epizootics and epidemics between 2000 and 2010 in Mato Grosso do Sul State. Electronic mail received by psilvadealmeida@yahoo.com.br in Nov, 2013.

33. Reinert JF. Revised list of abbreviations for genera and subgenera of Culicidae (Diptera) and notes on generic and subgeneric changes. J Am Mosq Control Ass 17: 51-55, 2001.

34. Ribeiro AF, Tengan C, Sato HK, Spinola R, Mascheretti M, França ACC, Port-Carvalho M, Pereira M, Souza RP, Amaku M, Burattini MN, Coutinho FAB, Lopez LF, Massad E. Public health risk assessment for yellow fever vaccination: a model exemplified by an outbreak in the state of São Paulo, Brazil. Mem Inst Oswaldo Cruz 110: 230-234, 2015. 
35. Romano APM, Ramos DG, Araújo FAA, Siqueira GAM, Ribeiro MPD, Leal SG, Elkhoury ANMS. Febre amarela no Brasil: recomendações para vigilância, prevenção e controle. Epidemiol Serv Saude 20: 101-106, 2011.

36. Romano APM, Costa ZGA, Ramos DG, Andrade MA, Jayme VS, de Almeida MAB, Vettorello KC, Mascheretti M, Flannery B. Yellow fever outbreaks in unvaccinated populations, Brazil, 2008-2009. PLoS Negl Trop Dis 8: e2740, 2014.

37. Sá ILR, Sallum MA. Comparison of automatic traps to capture mosquitoes (Diptera: Culicidae) in rural areas in the tropical Atlantic rainforest. Mem Inst Oswaldo Cruz 108: 1014-1020, 2013.

38. Secretaria de Planejamento e Coordenação Geral do Estado do Mato Grosso do Sul- SEPLANMS. Atlas Multirreferencial do Estado de Mato Grosso do Sul. Conv. Fundação IBGE (Solos, Vegetação, Geologia, Geomorfologia e Clima). Campo Grande, 1990.

39. Segura MNO, Castro FC. Atlas de culicídeos na Amazônia brasileira: características especificas de insetos hematófagos da família Culicidae. Instituto Evandro Chagas. Belém, 2007.

40. Silva AM, Silva JSV, Ferrari DL, Lamparelli RAC. Vegetação natural e área antrópica em Mato Grosso do Sul até o ano de 2002. Anais $3^{\circ}$ Simpósio de Geotecnologias no Pantanal. Embrapa Informática Agropecuária/INPE, 2010

41. Tauil PL. Aspectos críticos do controle da febre amarela no Brasil. Rev Saúde Pública 44: 555$558,2010$.

42. Tuboi SH, Costa ZGA, Vasconcelos PFC, Hatch D. Clinical and epidemiological characteristics of yellow fever in Brazil: analysis of reported cases 1998-2002. Trans R Soc Trop Med Hyg 101: 169-175, 2007.

43. Van der Stuyft P, Gianella A, Pirard M, Cespedes J, Lora J, Peredo C, Pelegrino JL, Vorndam V, Boelaert M. Urbanisation of yellow fever in Santa Cruz, Bolivia. Lancet 353: 1558-1562, 1999.

44. Vasconcelos PF, Rodrigues SG, Degallier N, Moraes MA, Da Rosa JF, Da Rosa ES, Da Rosa AP. An epidemic of sylvatic yellow fever in the southeast region of Maranhao State, Brazil, 1993-1994: epidemiologic and entomologic findings. Am J Trop Med Hyg 57: 132-137, 1997.

45. Vasconcelos PFC. Febre amarela. Rev Soc Bras Med Trop 36: 275-293, 2003.

46. Vasconcelos PFC. Yellow fever in Brazil: thoughts and hypotheses on the emergence in previously free areas. Rev Saúde Pública 44: 1144-1149, 2010.

47. Vasconcelos PFC, Quaresma JAS, Azevedo RSS, Martins LC. Febre amarela. In: Leão RNQ, Bichara CNC, Fraiha Neto H, Vasconcelos PFC. Medicina Tropical e infectologia na Amazônia. Samauma Editorial, Belém, 2013.

48. Yen C, Hyde TB, Costa AJ, Fernandez K, Tam JS, Hugonnet S, Huvos AM, Duclos P, Dietz VJ, Burkholder BT. The development of global vaccine stocpiles. Lancet Infec Dis 15: 340-347, 2015.

49. Zavattini JA. As chuvas e as massas de ar no estado de Mato Grosso do Sul: estudo geográfico com vista à regionalização climática. Editora UNESP; São Paulo: Cultura Acadêmica, 2009. 